\section{Incidence of congenital hypothyroidism in the city of Uberaba/Minas Gerais and etiological evaluation of the affected subjects}

\author{
Incidência do hipotireoidismo congênito no município de \\ Uberaba/Minas Gerais e avaliação etiológica dos afetados
}

Heloísa Marcelina da Cunha Palhares', Lilian Carla Silva², Luciene

Mayumi Sato', Beatriz Hallal Jorge Lara', Sybele de Souza Castro

Miranzi $^{3}$, Adriana de Paula Silva ${ }^{2}$, Maria de Fátima Borges ${ }^{1}$
Disciplina de Endocrinologia Universidade Federal do Triângulo Mineiro (UFTM), Uberaba, MG, Brasil ${ }^{2}$ UFTM, Uberaba, MG, Brasil ${ }^{3}$ Disciplina de Epidemiologia, UFTM, Uberaba, MG, Brasil live-born children screened. The etiological evaluation was done in 15 children and revealed seven cases of thyroid dysgenesis, seven of dyshormonogenesis, and one case of transient hypothyroidism. One child moved away from the state before etiological investigation was carried out. Conclusion: We concluded that both the incidence of $\mathrm{CH}$ and of dyshormonogenesis as the main causes of $\mathrm{CH}$ were increased in the investigated region, but molecular studies are necessary for a better definition of etiology. Arq Bras Endocrinol Metab. 2012;56(5):305-12

\title{
Keywords
}

Congenital hypothyroidism; newborn screening; epidemiology

\section{RESUMO}

Objetivo: O objetivo deste estudo foi determinar a incidência e etiologia do hipotireoidismo congênito $(\mathrm{HC})$ em Uberaba, MG. Pacientes e métodos: Mediante revisão dos prontuários de pacientes atendidos no ambulatório de referência do serviço público, no período de 2001 a 2010. Resultados: A cobertura do programa foi de $88 \%$, sendo diagnosticadas 16 crianças com HC, com incidência de 1:2.017 nascidos vivos investigados. A avaliação etiológica foi realizada em 15 crianças, sendo diagnosticados sete casos de disgenesia tireoidiana, sete casos de disormonogênese e um caso de hipotireoidismo transitório. Uma criança não foi investigada devido à mudança de residência para outro estado. Conclusões: Concluímos que a incidência do HC é maior nesta região, assim como a disormonogênese como principal causa, sendo necessários estudos moleculares para melhor definição etiológica. Arq Bras Endocrinol Metab. 2012;56(5):305-12

Correspondence to: Heloísa Marcelina da Cunha Palhares Disciplina de Endocrinologia, Departamento de Clínica Médica, Hospital de Clínicas,

Universidade Federal do Triângulo Mineiro

Av. Getúlio Guaritá, s/n 38025-440 - Uberaba, MG, Brasil helomcp@terra.com.br

Received on Mar/14/2012 Accepted on Jul/6/2012 


\section{INTRODUCTION}

Congenital hypothyroidism $(\mathrm{CH})$ is a clinical syndrome caused by thyroid hormone $(\mathrm{TH})$ deficiency, resulting in reduction of metabolic processes and impaired neurodevelopment. The disorder is classified as primary when the origin of the defect is in the gland itself, or secondary, when the hypothalamic-pituitary axis is affected (1-5).

Thyroid organogenesis and hormonogenesis and the structuring of the hypothalamic-pituitary-thyroid axis are essential early steps of embryonic life $(3,4,6)$. As the amount of $\mathrm{TH}$ that crosses the placenta is not sufficient to meet the needs of the fetus, fetal synthesis and secretion are important during the course of the gestation. Any interference that results in inadequate production of fetal $\mathrm{TH}$ represents a severe obstacle to the development of the synapses and neuronal myelination, which is clinically expressed by mental retardation and learning difficulties when the disorder is not diagnosed early and properly treated (4).

Based on newborn screening programs, the prevalence of primary $\mathrm{CH}$ is approximately $1: 3,000$ to $1: 4,000$. Some studies suggest an ethnic variation, with a higher prevalence among Hispanics and Native Americans $(1: 2,000)$ and a lower prevalence among Blacks (1:10,000), besides preponderance of female over the male gender $(2: 1)(3,5,7,8)$. The main causes of the disorder are: thyroid agenesis; ectopia due to a failure in embryonic migration of the gland; dyshormonogenesis caused by an inborn error of one of the many steps of thyroxin synthesis; and, finally, suppression of the fetal thyroid gland by medication used by the mother $(5,8)$.

The greatest challenge to control $\mathrm{CH}$ is neonatal detection by screening programs. The first programs of this kind were developed in Quebec (Canada) and Pittsburgh (USA) in 1974, using radioimmunoassay to measure TH in capillary blood samples obtained by heel puncture $(3,9)$. In Brazil, the Newborn Screening Program started in 1976 with a project to detect phenylketonuria (PKU), coordinated by Prof. Dr. Benjamin J. Schmidt and carried out at the São Paulo Association of Parents and Friends of the Mentally Handicapped (10). In 1983, the screening for PKU and CH by heel puncture became mandatory in the State of São Paulo for children born in public hospitals (State Law no. 3914, of November $14^{\text {th }}, 1983$ ), and in 1990 it was extended to children born in the whole country, both in public and in private healthcare facilities (Federal Law no. 8069 , of July $\left.13^{\text {th }}, 1990\right)(11,12)$.
Despite the existence of the Federal Law, the National Newborn Screening Program was only established in 2001 by the Ministry of Health (13), thereby starting the systematic screening of live-born Brazilian children, and ensuring the performance of all steps, from blood collection to treatment and follow-up of the detected cases, with funding provided by the Federal HealthCare System. In the State of Minas Gerais, the program is coordinated by the Nucleus of Actions and Research in Diagnostic Support, headquartered in the State capital Belo Horizonte, in collaboration with the Municipal Health Offices of the State of Minas Gerais.

According to the program protocol, blood for the neonatal screening test is ideally collected on the $5^{\text {th }}$ day of life, in order to ensure early diagnosis and onset of treatment. Once detected, the affected child is referred to a trained physician for follow-up. In Minas Gerais, this screening program was set up in 1993, and until 2008 a total of $3,574,476$ children had been screened (14).

The objective of the present study was to determine the incidence of $\mathrm{CH}$ in Uberaba, a medium-sized city of Minas Gerais, and to outline the screening, treatment and etiology of $\mathrm{CH}$ cases detected from 2001 to 2010.

\section{MATERIAL AND METHODS}

\section{Study protocol}

This is a descriptive, retrospective study, performed by reviewing patient records from a public reference outpatient unit for the treatment and follow-up of children with $\mathrm{CH}$ diagnosed by the State Newborn Screening Program. The study was approved by the Ethics Committee of the institution.

Neonatal screening has been systematically performed in all newborns in public healthcare facilities, and was analyzed since 2001 . The healthcare units are directed to collect blood samples between the $3^{\text {rd }}$ and $5^{\text {th }}$ day of life by heel puncture and impregnation of filter paper. The material is then sent to a reference laboratory, where it is processed and TSH levels are determined. Whenever TSH concentration is higher than $25 \mathrm{mIU} / \mathrm{L}$, parents are officially referred to the pediatric endocrinology outpatient clinic of the Hospital de Clínicas of the Federal University of Minas Gerais in Belo Horizonte, where the patient goes to a medical appointment and venous blood samples are drawn for $\mathrm{TSH}$, free T4, anti-thyroperoxidase antibody, and thyroglobulin measurements. 
Once $\mathrm{CH}$ is confirmed, i.e,. by serum TSH concentrations higher than $10 \mathrm{mIU} / \mathrm{L}$ and low free T4 (FT4), treatment is started with levothyroxine, $10-12 \mu \mathrm{g} / \mathrm{kg} /$ day. The child is referred to a local physician, trained to provide proper care. Borderline TSH values in the screening test (10-25 mIU/L) indicate the need to repeat blood collection on filter paper and, if confirmed (TSH > $10 \mathrm{mIU} / \mathrm{L})$, serum measurement and medical evaluation are also required (Figure 1).

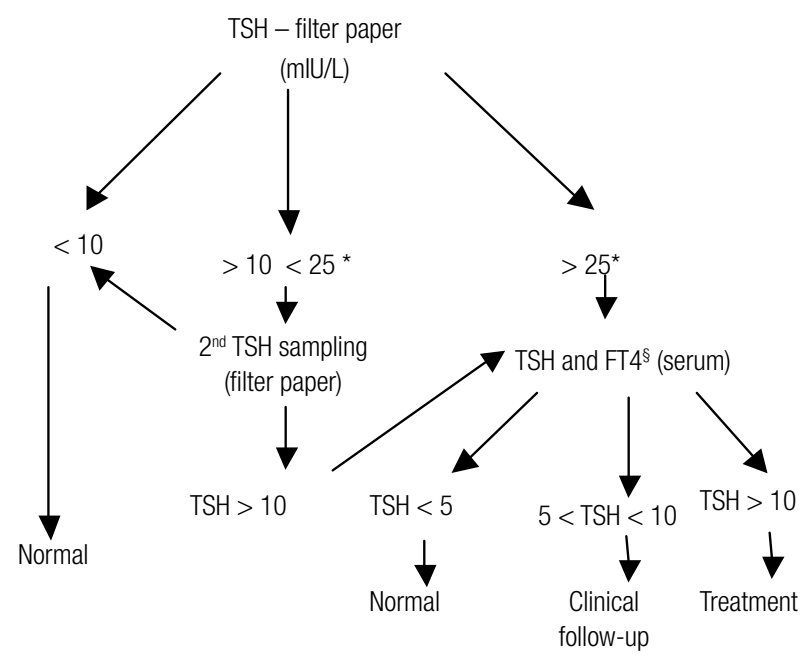

§ FT4: free T4

* Since 2007, TSH test level was changed to $<20 \mathrm{mlU} / \mathrm{L}$.

Figure 1. Protocol proposed by the Nucleus of Actions and Research in Diagnostic Support for newborn screening test analysis (Modified from Pezzuti IL, 2009).

Thereafter, the child is followed up by means of periodic medical examinations and L-thyroxine doses are adjusted according to clinical progress and periodic TSH and FT4 measurements.

After reaching three years of age, children have their medication suspended to determine $\mathrm{CH}$ etiology, and they undergo the following exams: thyroid scintigraphy with ${ }^{123} \mathrm{I}$, ultrasound, and perchlorate test, besides antithyroperoxidase antibodies and thyroglobulin measurements.

In the studied population, TSH analysis on filter paper was performed using ELISA (enzyme-linked immunosorbent assay; reference value $<10 \mathrm{mIU} / \mathrm{L}$ ), and serum TSH and FT4, anti-thyroperoxidase antibodies and thyroglobulin measurements were carried out by chemoluminescence (reference values: 0.3 to $5.0 \mu \mathrm{IU} /$ $\mathrm{mL} ; 0.75$ to $1.8 \mathrm{ng} / \mathrm{dL}$; and $<15 \mathrm{IU} / \mathrm{mL}$ and $<30$ $\mathrm{ng} / \mathrm{mL}$, respectively).
Clinical and laboratory data and the information obtained by the protocol (baby's age upon the first medical appointment, gender, clinical signs, and symptoms suggestive of $\mathrm{CH}$, age at screening, value of the first serum TSH and FT4 measurements, age at the beginning of treatment and etiology of the $\mathrm{CH}$ ) were analyzed.

\section{Statistics}

All observations were recorded in a database, using Excel 7.0 $\left(\right.$ Microsoft $\left.^{\circledR}\right)$ and GraphPad 5.0 (Graph Pad Prism $\left.^{\circledR}\right)$. Descriptive analysis based on absolute frequencies and percentages was used for the categorical variables, and measures of centrality (mean and median) and dispersion (standard deviation, coefficient of variation, minimum and maximum) were used for numerical variables. Data are presented in tables.

To calculate coverage, the following formula was used:

Coverage $=$ number of local live-born babies screened during the year in the city $\times 100$ total number of live-born babies during the year in the city

The formula used to calculate the incidence coefficient per year was:

Incidence coefficient $=\frac{\text { number of tests performed during the year in the city }}{\text { number of live-born babies screened during the }} \times 1000$

Taking into account that the incidence of a disease is defined as the number of new cases that occur within a certain period of time in a population exposed to the risk of getting sick (15), we considered for the incidence calculation of each time period the number of confirmed cases screened by means of the newborn test, and the total number of newborn tests performed by the public healthare system from 2001 to 2010 .

\section{RESULTS}

From 2001 through 2010 , a total of 36,666 babies were born in Uberaba/MG, and 32,278 of them underwent the newborn screening test provided by the public healthcare system. Thus, $88 \%$ of the babies were screened for $\mathrm{CH}$, and 16 cases were detected, indicating a $\mathrm{CH}$ incidence of 1 : 2,017 screened newborns during this period (2001-2010).

The percent coverage of the screening test varied from $84 \%$ to $92 \%$ and $\mathrm{CH}$ incidence coefficient varied from 0.00 to 1.25 cases/1,000 live-born children/year. 
Of the 16 babies diagnosed with $\mathrm{CH}, \mathrm{ll}(68.8 \%)$ were female, representing a Female/Male ratio of 2.2:1.

Gestations of most of the babies with $\mathrm{CH}(\mathrm{n}=$ 15 ; 93.8\%) were normal; in one case, pre-eclampsia and gestational diabetes occurred. Half of the deliveries were normal and at term; one was normal but post-term (42 weeks), five babies were delivered by cesarean section, and two by pre-term cesarean section (34 and 36 weeks). Eight babies (50\%) presented prolonged neonatal jaundice. One baby, small for gestational age at birth, had trisomy 21 . In seven babies $(43.8 \%)$, the screening test was positive, but signs did not suggest hypothyroidism. In the baby with trisomy 21 , the characteristics of the syndrome were predominant. The other eight babies (50\%) showed manifest hypothyroidism, with pale, dry, and rough skin or cutis marmorata, macroglossia, open anterior and posterior fontanels, umbilical hernia, and infiltrated appearance.

The newborn screening test was performed on the $5^{\text {th }}$ day of life in five of the babies diagnosed with $\mathrm{CH}$, and between the $5^{\text {th }}$ and $10^{\text {th }}$ day in eight babies (mean of $7 \pm 2$ days). Three babies had their tests delayed (performed at 17, 20, and 30 days of life, respectively) due to intercurrences at birth.

Once the diagnosis was confirmed, therapy was started between day 14 and 59 after birth (median: 32 days; Table 1). Excluding the cases of late blood collection and/or recall, mean time of treatment onset was at $24.2 \pm 10.2$ days ( 14 to 48 days).

Of the 16 babies diagnosed with $\mathrm{CH}, 6$ (37.5\%) presented TSH $<25 \mathrm{mIU} / \mathrm{L}$ upon the first screening test, so a second blood sample was collected on filter paper, which delayed the diagnosis.

The babies' first medical visit occurred at 14 to 59 days of age (median: 32 days), when they presented the anthropometric characteristics listed in table 1.

TSH concentrations obtained in the newborn screening test, TSH and free T4 measurements performed later on, and anti-thyroperoxidase and thyroglobulin values are presented in table 2 . Anti-thyroid antibodies at low concentrations do not support the existence of intrauterine autoimmune thyroiditis. There was one case with a rather low thyroglobulin level, and $\mathrm{CH}$ etiology in this patient is still being investigated (ultrasound showed normal topic thyroid).

An etiologic investigation was carried out in $\mathbf{1 5}$ children, between 3 and 4 years of age; one patient moved away from the State before the etiologic investigation was carried out. Cervical ultrasound $(\mathrm{n}=$ 15) showed a topic thyroid in 12 cases $(80 \%)$, thyroid ectopia in one case $(6.7 \%)$, and in two cases the gland was not visualized. Among the topic thyroids,

Table 1. Clinical data on the children with $\mathrm{CH}$ at birth and at the onset of treatment (Uberaba/MG, 2001-2010)

\begin{tabular}{|c|c|c|c|c|c|c|c|c|}
\hline \multirow{2}{*}{ Case } & \multirow{2}{*}{ Gender } & \multicolumn{2}{|c|}{ At birth } & \multirow{2}{*}{$\begin{array}{l}\text { Age at } 1^{\text {st }} \\
\text { ST }^{*} \text { (days) }\end{array}$} & \multirow{2}{*}{$\begin{array}{c}\text { Age at } 2^{\text {nd }} \mathbf{S T}^{\star} \\
\text { (days) }\end{array}$} & \multicolumn{3}{|c|}{ Onset of treatment } \\
\hline & & Weight (g) & Length (cm) & & & Age (days) & Weight (g) & Length (cm) \\
\hline 1 & $F$ & 3,200 & 51 & 17.0 & 43 & 52.0 & 4,900 & 56.5 \\
\hline 2 & $\mathrm{~F}$ & 3,400 & 49 & 10.0 & - & 32.0 & 4,600 & 55.5 \\
\hline 3 & M & 3,310 & 47 & 30.0 & 42 & 55.0 & 4,400 & 53.0 \\
\hline 4 & $\mathrm{~F}$ & 3,250 & 51 & 5.0 & - & 48.0 & 4,700 & 56.0 \\
\hline 5 & $\mathrm{~F}$ & 1,280 & 37 & 20.0 & - & 59.0 & 2,450 & 44.5 \\
\hline 6 & $\mathrm{~F}$ & 3,000 & 49 & 5.0 & 20 & 33.0 & 3,700 & 49.0 \\
\hline 7 & $\mathrm{~F}$ & 2,550 & 47 & 5.0 & - & 24.0 & 3,100 & 49.0 \\
\hline 8 & $\mathrm{~F}$ & 3,150 & 51 & 9.0 & - & 23.0 & 3,700 & 51.0 \\
\hline 9 & M & 3,300 & 49 & 5.0 & 26 & 39.0 & 4,700 & 56.0 \\
\hline 10 & $\mathrm{~F}$ & 2,645 & 46 & 9.0 & 28 & 37.0 & 4,200 & 51.3 \\
\hline 11 & M & 3,165 & 45 & 10.0 & 33 & 45.0 & 3,800 & 50.5 \\
\hline 12 & M & 3,650 & 52 & 5.0 & - & 20.0 & 3,600 & 53.0 \\
\hline 13 & $\mathrm{~F}$ & 3,980 & 53 & 9.0 & - & 19.0 & 4,600 & 54.0 \\
\hline 14 & M & 3,360 & 48 & 7.0 & - & 18.0 & 3,700 & 49.5 \\
\hline 15 & $\mathrm{~F}$ & 3,100 & 49 & 7.0 & - & 20.0 & 3,200 & 52.0 \\
\hline 16 & $\mathrm{~F}$ & 2,750 & 47 & 7.0 & - & 14.0 & 2,900 & 48.0 \\
\hline Median & - & 3,182 & 49 & 8.0 & 30 & 32.0 & 4,000 & 52.0 \\
\hline Minimum & - & 1,280 & 37 & 5.0 & 20 & 14.0 & 2,450 & 44.5 \\
\hline Maximum & - & 3,980 & 53 & 30.0 & 43 & 59.0 & 4,900 & 57.5 \\
\hline
\end{tabular}


four were hypoplastic, six had normal volume, and two were enlarged. Scintigraphy was performed in $11(68.8 \%)$ children. In three of them $(27.2 \%)$, the thyroid was ectopic (sublingual), in the other cases
$(72.7 \%)$ it was topic. The perchlorate test, performed in eight children with topic thyroid, was positive in one case $(12.5 \%)$, indicating a defect in iodine organification (Table 3 ).

Table 2. Results of the screening test and hormone dosages confirming CH (Uberaba/MG, 2001-2010)

\begin{tabular}{|c|c|c|c|c|c|c|}
\hline \multirow[b]{2}{*}{ Case } & \multicolumn{2}{|c|}{ Filter paper } & \multicolumn{4}{|c|}{ Serum } \\
\hline & $\begin{array}{c}1^{\text {st }} \mathbf{S T}{ }^{\star} \\
\text { TSHmIU/L }\end{array}$ & $\begin{array}{c}2^{\text {nd }} \mathbf{S T}^{\star} \\
\text { TSHmIU/L }\end{array}$ & $\begin{array}{c}\text { TSH } \\
\mu \mathrm{lU} / \mathrm{mL}\end{array}$ & $\begin{array}{c}\mathrm{FT4} \\
\mathrm{ng} / \mathrm{dL}\end{array}$ & $\begin{array}{c}\text { Anti-TPO } \\
\text { IU/mL }\end{array}$ & $\begin{array}{c}\mathrm{TG}{ }^{\star *} \\
\mathrm{ng} / \mathrm{mL} \\
\end{array}$ \\
\hline 1 & 11.8 & 249.2 & 129.1 & 0.62 & 1.0 & $1,176.0$ \\
\hline 2 & 33.9 & - & 371.0 & 0.34 & 1.0 & 300.7 \\
\hline 3 & 13.8 & 10.8 & 13.8 & 1.35 & 3.0 & 94.3 \\
\hline 4 & 77.4 & - & 48.0 & 1.04 & 1.0 & 102.8 \\
\hline 5 & 134.0 & - & 138.2 & 0.78 & NT & NT \\
\hline 6 & 23.0 & 24.9 & 24.5 & 1.11 & 13.0 & 66.0 \\
\hline 7 & 27.2 & - & 11.5 & 1.08 & 1.0 & 21.1 \\
\hline 8 & 38.6 & - & 61.9 & 0.66 & 73.0 & 281.1 \\
\hline 9 & 10.8 & 33.1 & 15.7 & 1.02 & 1.0 & 483.0 \\
\hline 10 & 24.2 & 49.3 & 75.6 & 0.77 & 1.0 & 180.0 \\
\hline 11 & 22.6 & 13.7 & 32.4 & 0.91 & 1.0 & 61.2 \\
\hline 12 & 119.3 & - & 317.4 & 0.50 & NT & NT \\
\hline 13 & 164.7 & - & 397.4 & 0.40 & 1.0 & 0.1 \\
\hline 14 & 30.0 & - & 166.5 & 0.53 & 3.0 & 66.4 \\
\hline 15 & 150.0 & - & 500.0 & 0.01 & 3.0 & 66.1 \\
\hline 16 & 34.2 & - & 108.0 & 0.21 & 2.0 & 737.3 \\
\hline Median & 34.0 & 29.0 & 91.8 & 0.71 & 1.0 & 98.6 \\
\hline Minimum & 10.8 & 10.8 & 11.5 & 0.01 & 1.0 & 0.1 \\
\hline Maximum & 164.7 & 249.2 & 500.0 & 1.35 & 73.0 & 1176.0 \\
\hline
\end{tabular}

TSH: 0.3 to $5.0 \mu \mathrm{lU} / \mathrm{mL} ;$ FT4: 0.75 to $1.8 \mathrm{ng} / \mathrm{dL} ;$ ANTI-TPO: $<15 \mathrm{IU} / \mathrm{mL} ;$ TG: up to $30 \mathrm{ng} / \mathrm{mL}$.

* ST: screening test; ** TG: thyroglobulin; NT: not tested.

Table 3. Results of etiologic and diagnostic tests of children with CH (Uberaba/MG, 2001-2010)

\begin{tabular}{|c|c|c|c|c|c|c|}
\hline Case & $\begin{array}{c}\text { TSH } \\
\mu \mathrm{IU} / \mathrm{mL}\end{array}$ & $\begin{array}{c}\text { FT4 } \\
\mathrm{ng} / \mathrm{dL}\end{array}$ & $\begin{array}{c}\text { Thyroid characteristics at } \\
\text { ultrasound }\end{array}$ & Scintigraphy & $\begin{array}{l}\text { Perchlorate } \\
\text { test }\end{array}$ & Diagnosis \\
\hline 1 & 11.0 & 1.38 & Topic; normal volume & Topic & Positive & Defect in iodine organificaion \\
\hline 2 & 10.5 & 1.08 & Topic; left lobe hypoplastic & Topic & Negative & Left lobe hypoplastic \\
\hline 3 & 10.0 & 1.33 & Topic; enlarged & Topic & Negative & Dyshormonogenesis \\
\hline 4 & 65.6 & 0.96 & Topic; normal volume & Topic & Negative & Dyshormonogenesis \\
\hline 5 & 20.4 & 1.28 & Topic; hypoplastic & Topic & Negative & Hypoplasia \\
\hline 6 & 72.9 & 1.36 & Ectopic & Ectopic & Not done & Ectopia \\
\hline 7 & 11.3 & 0.81 & Topic; normal volume & Topic & Negative & Dyshormonogenesis \\
\hline 8 & 320.1 & 0.05 & Topic; hypoplastic & Topic & Negative & Hypoplasia \\
\hline 9 & 6.5 & 0.87 & Topic; normal volume & Topic & Negative & Transient hypothyroidism \\
\hline 10 & NT & NT & Topic; hypoplastic & Not done & Not done & Probable hypoplasia \\
\hline 11 & NT & NT & Topic; normal volume & Not done & Not done & Probable dyshormonogenesis \\
\hline 12 & 476.1 & 0.25 & Not visualized & Ectopic & Not done & Ectopia \\
\hline 13 & NT & NT & Topic; normal volume & Not done & Not done & Probable dyshormonogenesis \\
\hline 14 & 377.1 & 0.25 & Not visualized & Ectopic & Not done & Ectopia \\
\hline 15 & NT & NT & Not done & Not done & Not done & Moved away from the State \\
\hline 16 & NT & NT & Topic; enlarged & Not done & Not done & Probable dyshormonogenesis \\
\hline
\end{tabular}

TSH: 0.3 to $5.0 \mu \mathrm{ll} / \mathrm{mL} ;$ FT4: 0.75 to $1.8 \mathrm{ng} / \mathrm{dL}$.

NT: not tested. 
Of the children investigated thoroughly, only one case had transient hypothyroidism, so the medication was discontinued. This child was nevertheless followed up for other 2 years and, as he remained euthyroid, he was discharged from the program. Ten of the remaining children were diagnosed with permanent hypothyroidism and resumed the treatment with sodium levothyroxine. Currently, four children are waiting for a complementation of their etiologic investigation (scintigraphy and perchlorate test) while under treatment.

Neuropsychomotor development has been considered adequate for age in 12 children, except for one who presented neonatal seizures and the patient with trisomy 21. Six children are already at school age and six are at preschool age.

\section{DISCUSSION}

Access to the newborn screening test is still highly variable in Brazil, ranging from virtually $100 \%$ in the southern states to less than $60 \%$ in the northern states of the country, where geographic, political, economic, social, cultural, and educational barriers still persist (16).

In the State of Minas Gerais, the coverage of the newborn screening program is $94.6 \%$ (17) and comprises almost $100 \%$ of the 853 cities of the state. In Uberaba, this coverage has been maintained over the years at around $88 \%$, and we believe that the remaining babies are screened by the private healthcare system, since the socioeconomic conditions of part of the population allows them to afford private healthcare. This assumption is corroborated by 2003 data showing that almost one fourth of the Brazilian population (24.6\%) was covered by private health insurance plans (18). This overall coverage rate is similar to the States of Paraná and Santa Catarina, which in 2007 presented an 88\% and $88.5 \%$ coverage, respectively (19), and higher than in states of Pernambuco and Piauí, where in 2007 only $51 \%$ and $64 \%$ of the live-born babies were screened, respectively (20), and Sergipe, where in 2005 the coverage was $76.3 \%(21)$.

The incidence of $\mathrm{CH}$ in Uberaba is higher $(1: 2,017)$ than the reported by most of the newborn screening programs in Brazil. This city is situated in a well-developed region of the State of Minas Gerais that has been considered iodine-deficient in the past. However, there is no recent data on the regional iodine status (22). The greater number of cases may also be due to not yet identified environmental factors. An even higher inci- dence was observed in the State of Rio de Janeiro from 2005 to 2007 (1:1,030). This finding was attributed to variations in the neonatal TSH cutoff values among the screening models used there (23). According to a Brazilian newborn screening epidemiologic survey, in 2001, the prevalence of $\mathrm{CH}$ was $1: 3,694$, and in 2002, it was $1: 3,808(24)$.

Ideally, the age for collecting the first blood sample for TSH screening is between the $3^{\text {rd }}$ and the $5^{\text {th }}$ day of life, when the postnatal peak of physiological TSH elevation has already decreased (25-27). In Uberaba, the mean age at the first blood collection of the diagnosed patients was 7 days, except for the three cases with late blood collection due to various reasons. This value is similar to the newborn screening program of the city of Ribeirão Preto, state of São Paulo (8 days) (12), but higher than the limits established as ideal in the Administrative Rule no. 822 (13) of the Brazilian Ministry of Health (2 to 7 days of life). Compared with other Brazilian states, the mean of 7 days is higher than the one found in the states of Paraná ( 3 days) and Santa Catarina ( 5 days), but lower than in Rio Grande do Sul (11 days) (19) and in Paraíba (29.8 days) (28). In a study published in 2006 on $\mathrm{CH}$ screening in Scotland (29), the median age at blood collection for the test was 6 days, and $93.8 \%$ of the samples were collected before eight days of life.

Treatment was started on average at 24.6 days of life and, in the last 4 years, it was observed that, even if the screening test was not carried out exactly on the $5^{\text {th }}$ day, but between the $5^{\text {th }}$ and the $10^{\text {th }}$ day, treatment was started before 20 days of age. This observation proves how fast samples are sent to the reference laboratory, results are provided, and the children officially called in for medical examination, confirmation of the diagnosis, and onset of treatment. In a further effort to start treatment as early as possible, ideally by the second week of life, the Newborn Screening Program of the State of Minas Gerais has called in children with TSH test results higher than $20 \mathrm{mIU} / \mathrm{L}$ (rather than 25) for a medical examination since 2007 (30). In the long run, this intervention will certainly show an impact on achieving the desired results.

Comparing the data of the present study with those of other Brazilian newborn screening programs, we observed a similarity in treatment onset with the program performed at the Ribeirão Preto School of Medicine University Hospital, equal to $25.9 \pm 14.2$ days (12), and in the State of Rio Grande do Sul, where it was 24 
days (19). It is, however, still longer than in the States of Paraná (15 days) and Santa Catarina (16 days) (data for 2007) (19). National data obtained by the Brazilian Society of Newborn Screening for the years 2001 and 2002 showed that the mean age at start of $\mathrm{CH}$ treatment was $34 \pm 17$ days (19). In the Scottish study (29), the median age at treatment start was 11 days, but $12 \%$ of the evaluated children started treatment at over 16 days of life, which was considered late.

In order to be able to start treatment as early as possible, campaigns directed to healthcare professionals have been conducted in Uberaba, so that they would instruct parents regarding the importance of early testing (up to the $5^{\text {th }}$ day of life), and alert the basic healthcare unit professionals about the importance of collecting blood samples properly, and quickly sending them to the reference laboratory.

So far, the analysis of $\mathrm{CH}$ etiology confirmed six cases of thyroid dysgenesis and four cases of dyshormonogenesis. Four cases are still under investigation (probable dysgenesis in one case and dyshormonogenesis in three). Compared with the literature, where thyroid dysgenesis is predominant (9,31-34), in the $\mathrm{CH}$ patients of Uberaba, dyshormonogenesis was observed to have a higher frequency. One case of iodine organification defect and three cases with a normal perchlorate test were also found. In three children with a topic thyroid on ultrasound, scintigraphy and perchlorate test are still to be performed, and molecular studies will be necessary in the future for a better etiologic definition. We raised the possibility of parental consanguinity (35) as the factor responsible for this finding, but information obtained from the parents did not confirm this hypothesis. The results found in Uberaba are consistent with a study carried out on 243 patients with $\mathrm{CH}$ from the Newborn Screening Program of the State of Minas Gerais from 1996 to 2003, which also observed a higher frequency of hormone synthesis defects (52\%) than thyroid dysgenesis (47\%) (36).

$\mathrm{CH}$ is one of the most common causes of preventable mental retardation, and its natural course can be dramatically modified depending on how early it is diagnosed and how quickly proper treatment is started. Thus, every effort should be made to carry out newborn screening programs, in order to ensure early diagnosis and treatment. To reach this goal, it is important to set time patterns for each step of the screening process, because delays in one or more steps will lead to unacceptable delays in the treatment of the affected children. The Newborn Screening Program of the State of Minas Gerais is actively attempting, together with the municipal health offices, to overcome the difficulties and, consequently, reach the desired goals. Specifically in Uberaba, it is still necessary to optimize the extent of program coverage, and to reduce the age at sample collection. However, promising results are already being obtained, offering a better perspective to the patients.

Acknowledgments: the authors are grateful to the Health Office of Uberaba/MG and to the Nucleus of Actions and Research in Diagnostic Support of the Federal University of Minas Gerais for giving them access to all the records, and to Ms. Silvana Silva, social worker of the Newborn Screening Program of the City of Uberaba, for her invaluable help.

Disclosure: no potential conflict of interest relevant to this article was reported.

\section{REFERENCES}

1. Cooper DS, Greenspan FS, Ladenson PW, Oxon MA. The thyroid gland. In: Greenspan FS, Gardner DG, editors. Basic \& Clinic Endocrinology. 8th ed. New York: McGraw-Hill; 2007. p. 209-80.

2. Medeiros-Neto G, Knobel M. Hipotireoidismo congênito. In: Monte O, Longui CA, Calliari PE, Kochi C, editors. Endocrinologia para o pediatra. 3th ed. Atheneu; 2007. p. 819-39.

3. Rapaport $R$, Simpser T. Update on some aspects of neonatal thyroid disease. J Clin Res Ped Endo. 2010;2(3):95-9.

4. Setian N. Hypothyroidism in children: diagnosis and treatment. J Pediatr (Rio J). 2007;83(5 Supl):209-16.

5. Dantas M, Miguel D, Pereira M, Toralles MB, Alves C. A importância da triagem neonatal no hipotireoidismo congênito: análise secundária de dados. Gaz Méd Bahia. 2007;77(1 Supl):82-7.

6. Knobel M, Nogueira CR, Medeiros-Neto G. Genética molecular do hipotireoidismo congênito. Arq Bras Endocrinol Metab. 2001;45(1):24-31.

7. Maciel LM. Hipotireoidismo congênito. Projeto Diretrizes - Associação Médica Brasileira e Conselho Federal de Medicina. 2006. p. 10. Avaiable at: <http://www.projetodiretrizes.org.br/4_ volume/18-Hipotiroid.pdf >. Accessed on: Nov 10, 2011.

8. LaFranchi S. Congenital hypothyroidism: etiologies, diagnosis, and management. Thyroid. 1999;9(7):735-40.

9. American Academy of Pediatrics, Rose SR; Section on Endocrinology and Committee on Genetics, American Thyroid Association, Brown RS; Public Health Committee, Lawson Wilkins Pediatric Endocrine Society, Foley T, Kaplowitz PB, Kaye CL, Sundararajan S, Varma SK. Update of neonatal screening and therapy for congenital hypothyroidism. Pediatrics. 2006;117(6):2290-303.

10. Carvalho TM, Santos HP, Santos IC, Vargas PR, Pedrosa J. Neonatal screening: a national public health programme in Brazil. J Inherit Metab Dis. 2007;30(4):615.

11. Tuoto EA. História da Medicina - O Teste do pezinho no Brasil. Avaiable at: <http:// historyof medicine.blogspot.com/2007>. Accessed on: Nov 10, 2011.

12. Magalhães PKR, Turcato MF, Ângulo IL, Maciel LMZ. Neonatal Screening Program at the University Hospital of the Ribeirão Preto School of Medicine, São Paulo University, Brazil. Cad Saúde Pública. 2009;25(2):445-54. 
13. Ministério da Saúde. Portaria $n^{\circ} .822$, de 06 de junho de 2001. Avaiable at: <http://dtr2001.saude.gov.br/sas/PORTARIAS/Port2001/GM/ GM-822.htm>. Accessed on: Nov 10, 2011.

14. Chagas AJ. Rastreamento neonatal em Minas Gerais. In: Medeiros-Neto $G$, Knobel $M$, editors. Hipotireoidismo congênito no Brasil: desafios à busca de soluções. São Paulo: Conectfarma Publicações Científicas, 2008. p. 77-9.

15. Laprega MR, Fabro ALD. Coeficientes e índices mais usados em epidemiologia. In: Franco LJ, Passos ADC, editors. Fundamentos de epidemiologia. $2^{\mathrm{a}}$ ed. Barueri, SP: Manole, 2011. p. 117-48.

16. Martinho LP. Dificuldades de triagem na região norte. In: Medeiros-Neto G, Knobel M, editors. Hipotireoidismo congênito no Brasil: desafios à busca de soluções. São Paulo: Conectfarma Publicações Científicas, 2008. p. 87-8.

17. Dias VMA. Exposição de Centros de Referência Regionais - Região Sudeste. In: Medeiros-Neto G, Knobel M, editors. Hipotireoidismo congênito no Brasil: desafios à busca de soluções. São Paulo: Conectfarma Publicações Científicas, 2008. p.103-6.

18. Brasil, Indicadores Básicos para a Saúde no Brasil: conceitos e aplicações. Rede Interagencial de Informação para a Saúde Ripsa. $2^{a}$. ed. Brasília: Organização Pan- Americana da Saúde, 2008. p. 349: il. Avaiable at: <http:/tabnet.datasus.gov.br/tabdata/ livroidb/2ed/apresent.pdf>. Accessed on: Out 21, 2011.

19. Vargas PR. Exposição de Centros de Referência Regionais - Região Sul. In: Medeiros-Neto G, Knobel M, editors. Hipotireoidismo congênito no Brasil: desafios à busca de soluções. São Paulo: Conectfarma Publicações Científicas, 2008. p. 107-9.

20. Geroldo SR. Exposição de Centros de Referência Regionais - Região Nordeste. In: Medeiros-Neto G, Knobel M, editors. Hipotireoidismo congênito no Brasil: desafios à busca de soluções. São Paulo: Conectfarma Publicações Científicas, 2008. p. 95-8.

21. Ramalho ARO, Ramalho RJR, Oliveira CRP, Santos EG, Oliveira MCP, Aguiar-Oliveira MH. Programa de Triagem Neonatal para Hipotireoidismo Congênito no Nordeste do Brasil: Critérios Diagnósticos e Resultados. Arq Bras Endocrinol Metab. 2008;52(4):617-27.

22. Lima MA, Fagundes TA, Raffaelli CM, Ferreira BP, Resende EM, Fonseca EC, et al. Alcoholization in the treatment of thyroid nodule in colloid goiter endemic region. Arq Bras Endocrinol Metab. 2007;51(6):1007-12.

23. Botler J. Avaliação de desempenho do programa de triagem neonatal do estado do Rio de Janeiro. 2010. 239f. Tese (Doutorado em Saúde Pública) - Escola Nacional de Saúde Pública Sergio Arouca, Rio de Janeiro, 2010.
24. Sociedade Brasileira de Triagem Neonatal. Dados estatísticos 2002/2003. Avaiable at: <http://www.sbtn.org.br>. Accessed on: Out 10, 2011.

25. American Academy of Pediatrics AAP Section on Endocrinology and Committee on Genetics, American Thyroid Association Committee on Public Health. Neonatal screening for congenital hypothyroidism: recommended guidelines. Pediatrics. 1993;91:1203-9.

26. Fisher DA. Clinical review 19: management of congenital hypothyroidism. J Clin Endocrinol Metab. 1991;72:523-9.

27. Fisher DA. Physiological variations in thyroid hormones: physiological and pathophysiological considerations. Clin Chem. 1996;42(1):135-9.

28. Ramos AJS, Rocha AM, Costa ADM, Benicio AVL, Ramos ALC, Silva CRA, et al. Avaliação do programa de rastreamento de doenças congênitas em Campina Grande-PB, Brasil. Arq Bras Endocrinol Metab. 2003;47(3):280-4.

29. Jones JH, Mackenzie J, Croft GA, Beaton S, Young D, Donaldson MD. Improvement in screening performance and diagnosis of congenital hypothyroidism in Scotland 1979-2003. Arch Dis Child. 2006;91:680-5.

30. Pezzuti IL, Lima PP, Dias VMA. Congenital hypothyroidism: the clinical profile of affected newborns identified by the neonatal screening Program of the State of Minas Gerais, Brazil. J Pediatr (Rio J). 2009;85(1):72-9.

31. Ramos HE, Nesi-França S, Boldarine VT, Pereira RM, Chiamolera $\mathrm{MI}$, Camacho $\mathrm{CP}$, et al. Clinical and molecular analysis of thyroid hypoplasia: a population-based approach in Southern Brazil. Thyroid. 2009;19(1):61-8.

32. Rubio IGS, Knobel M, Nascimento AC, Santos CL, Toniolo JV, Medeiros-Neto G. Hipotireoidismo congênito: recentes avanços em genética molecular. Arq Bras Endocrinol Metab. 2002;46(4):391-401.

33. Perone D, Teixeira SS, Clara SA, Santos DC, Nogueira CR. Aspectos genéticos do hipotireoidismo congênito. Arq Bras Endocrinol Metab. 2004;48(1):62-9.

34. Toniolo JV, Kopp P. Thyroglobulin gene mutations and other genetic defects associated with congenital hypothyroidism. Arq Bras Endocrinol Metab. 2004;48(1):70-82.

35. Hashemipour M, Amini M, Talaie M, Kelishadi R, Hovespian S, Iranpour $\mathrm{R}$, et al. Parental consanguinity among parents of neonates with congenital hypothyroidism in Isfahan. East Mediterr Health J. 2007;13(3):567-74.

36. Dias VM, Campos AP, Chagas AJ, Silva RM. Congenital hypothyroidism: etiology. J Pediatr Endocrinol Metab. 2010;23(8): 815-26. 